\title{
Barriers, Enablers, and Perceptions on Dietary Salt Reduction in the Out-of-Home Sectors: A Scoping Review
}

\author{
Viola Michael ${ }^{1,2}$, Yee Xing You ${ }^{1}$, Suzana Shahar ${ }^{1, *}$, Zahara Abdul Manaf ${ }^{1}$, Hasnah Haron ${ }^{3}$, \\ Siti Nurbaya Shahrir ${ }^{2}$, Hazreen Abdul Majid ${ }^{4,5}{ }^{(}$, Yook Chin Chia ${ }^{6,7}$, Mhairi Karen Brown ${ }^{8}$, \\ Feng J. $\mathrm{He}^{8}\left[\right.$ and Graham A. MacGregor ${ }^{8}$
}

Citation: Michael, V.; You, Y.X.; Shahar, S.; Manaf, Z.A.; Haron, H.; Shahrir, S.N.; Majid, H.A.; Chia, Y.C.; Brown, M.K.; He, F.J.; et al. Barriers, Enablers, and Perceptions on Dietary Salt Reduction in the Out-of-Home Sectors: A Scoping Review. Int. J. Environ. Res. Public Health 2021, 18, 8099. https://doi.org/10.3390/ ijerph18158099

Academic Editor: Agnieszka Jaworowska

Received: 10 May 2021

Accepted: 27 July 2021

Published: 30 July 2021

Publisher's Note: MDPI stays neutra with regard to jurisdictional claims in published maps and institutional affiliations.

Copyright: (C) 2021 by the authors Licensee MDPI, Basel, Switzerland. This article is an open access article distributed under the terms and conditions of the Creative Commons Attribution (CC BY) license (https:// creativecommons.org/licenses/by/ $4.0 /)$.
1 Dietetics Programme and Centre for Healthy Ageing and Wellness (H-Care), Faculty of Health Sciences, Universiti Kebangsaan Malaysia, Jalan Raja Muda Abdul Aziz, Kuala Lumpur 50300, Malaysia; violamichael@moh.com.my (V.M.); youyeexing@ukm.edu.my (Y.X.Y.); zaharamanaf@ukm.edu.my (Z.A.M.)

2 Disease Control Division, Ministry of Health Malaysia, Putrajaya 62590, Malaysia; drsitinurbaya@gmail.com

3 Nutritional Sciences Programme and Centre for Healthy Ageing and Wellness (H-Care), Faculty of Health Sciences, Universiti Kebangsaan Malaysia, Jalan Raja Muda Abdul Aziz, Kuala Lumpur 50300, Malaysia; hasnaharon@ukm.edu.my

4 Centre for Population Health, Department of Social and Preventive Medicine, Faculty of Medicine, University of Malaya, Kuala Lumpur 50603, Malaysia; hazreen@ummc.edu.my

5 Department of Nutrition, Faculty of Public Health, Universitas Airlangga, Jawa Timur 60115, Indonesia

6 Department of Medical Sciences, School of Medical and Life Sciences, Sunway University, Petaling Jaya, Selangor Darul Ehsan 47500, Malaysia; ycchia@sunway.edu.my

7 Department of Primary Care Medicine, Faculty of Medicine, University of Malaya, Kuala Lumpur 50603, Malaysia; chiayc@um.edu.my

8 Wolfson Institute of Preventive Medicine, Barts and The London School of Medicine and Dentistry, Queen Mary University of London, London EC1M 6BQ, UK; mhairi.brown@qmul.ac.uk (M.K.B.); f.he@qmul.ac.uk (F.J.H.); g.macgregor@qmul.ac.uk (G.A.M.)

* Correspondence: suzana.shahar@ukm.edu.my

Abstract: In this review, we have investigated the perceptions, barriers, and enabling factors that were responsible for a dietary salt reduction in the out-of-home sectors. For this purpose, we examined different knowledge databases such as Google Scholar, Ebscohost, MEDLINE (PubMed), Ovid, and Cochrane Library for research articles from September to December 2020. The inclusion criteria for the research articles were that they had to be published in English and had to be a qualitative or quantitative study that was conducted after 2010. These studies also had to report the various enablers, barriers, and perceptions regarding salt reduction in the out-of-home sectors. After implementing the inclusion criteria, we successfully screened a total of 440 studies, out of which 65 articles fulfilled all the criteria. The perceived barriers that hindered salt reduction among the outof-home sectors included lack of menu and food variabilities, loss of sales due to salt reduction, lack of technical skills for implementing the salt reduction processes for cooking or reformulation, and an absence of environmental and systemic support for reducing the salt concentration. Furthermore, the enablers for salt reduction included the intervention programs, easy accessibility to salt substitutes, salt intake measurement, educational availability, and a gradual reduction in the salt levels. With regards to the behavior or perceptions, the effect of organizational and individual characteristics on their salt intake were reported. The majority of the people were not aware of their salt intake or the effect of salt on their health. These people also believed that low salt food was recognized as tasteless. In conclusion, the enablers, barriers, and perceptions regarding salt reduction in the out-of-home sectors were multifaceted. Therefore, for the implementation of the strategies, policies, and initiatives for addressing the barriers, the policymakers need to encourage a multisectoral collaboration for reducing the salt intake in the population.

Keywords: barriers; enablers; perception; salt reduction; out-of-home 


\section{Introduction}

A majority of the countries, worldwide, have undertaken steps to decrease the salt intake in their population. Most of the salt reduction strategies such as legislation, reformulation, and salt reduction intervention programmes were suggested by the industries as well as governmental and non-governmental organizations [1,2]. Despite the probable health benefits of a low salt intake, very few researchers have investigated the implementation of the salt reduction intervention for achieving a sustained reduction of salt intake among the Low- and Middle-Income Countries (LMICs) [3,4]. It was noted that translational research could help in determining the available intervention steps which were effective and suitable for various contexts. In an earlier study, the researchers concluded that based on the moderate quality of the evidence, the population-level interventions could improve the salt-related behaviour of the people [5].

A systematic review conducted by Cappuccio et al. (2015) indicated that some of the successful policies included comprehensiveness, which involved health education, population monitoring, and reformulation for decreasing the salt concentration included in the processed foods (responsible for $\geq 75 \%$ of the daily salt intake) [6]. These populationbased salt reduction policies were rapid, equitable, powerful, and enabled cost saving.

The United Kingdom developed an excellent and popular national salt reduction strategy in 2003. These policies included three major factors, i.e., improved nutrition labelling, consumer awareness campaigns, and a government-backed salt reduction model which set low salt targets for more than 85 different food categories that had to be achieved by the food manufacturers within a specified time frame [7]. This resulted in a $15 \%$ decrease in the salt intake within the population in the United Kingdom (from 9.5 to $8.1 \mathrm{~g} /$ day, in the period ranging from 2001 to 2011) [7]. Very few studies have shown that salt intake was influenced by income. Azizan et al. (2020) carried out an intervention study and noted that dietary modification could improve the nutritional intake such as the salt intake and the biochemical profile of the low-income urban population suffering from hypertension in Malaysia [8].

The out-of-home sector consists of the outlets which serve foods and drinks for immediate consumption or take away. This sector includes formal and informal sections. A formal out-of-home sector that includes the licensed and registered cafes, restaurants, school/work canteens, fast food outlets, takeaways, food delivery services or hotel restaurants. On the other hand, the informal out-of-home sector includes street hawkers, food vendors, and food delivery services [9].

Commonly, many people worldwide, are choosing to dine outside their homes $[10,11]$. A survey was carried out in the USA, which showed that $\geq 50 \%$ of the adults eat out more than 3 times per week, while 35\% of the adults eat fast food meals at least 2 times every week [12]. In 2012, another study was conducted in China, where the researchers determined the relationship between the nutritional status of the residents and the onset of chronic diseases. The researchers noted that $35.5 \%$ of the residents, aged above 6 years preferred dining out. Out of these, $42.2 \%$ were urban residents, while $28.5 \%$ of the people were rural residents [13]. The home-cooked meals were regarded as healthier compared to those purchased from out-of-home places [14,15]. Furthermore, the out-of-home meals contained higher levels of salt, added sugar and saturated fats, while they were also low in vitamins, fiber, and minerals compared to the home-cooked meals [16]. The research question for this review paper is "What are the barriers, enablers and perceptions on dietary salt reduction in the out-of-home sectors?" Hence, this review was carried out for identifying the different barriers, motivators, and perceptions of the people regarding the reduction of dietary salt levels in out-of-home meals. This review would also help in identifying the different strategies that can be used for salt levels reduction.

\section{Materials and Methods}

In this study, the researchers have adopted the framework proposed by Arksey and O'Malley (2005) for scoping different reviews [17], along with the enhanced and adapted 
methodologies proposed by Levac et al. (2010) and Daudt et al. (2013) [18,19]. Based on all these frameworks, the researchers implemented five stages, such as (i) Identifying research questions; (ii) Determining important studies; (iii) Selection of the studies; (iv) Charting data; and (v) Collating, summarizing, and presenting all the results. This framework is the most commonly used framework in the scoping review. The researchers did not use ethical registration since this was a scoping review.

\subsection{Identification of the Relevant Study}

A search strategy was developed collectively. Regular discussions and meetings were conducted for determining the significance of all citations and resolving disagreements. The first author (V.M.) primarily conducted the search and two co-authors (Y.X.Y. and S.N.S.) independently searched using the same keywords. Consolidation of articles to be included in the review was done among these three authors. Some inclusion criteria were set before selecting the citations. These criteria stated that the study must be published in the English language, must be peer-reviewed or grey literature, and must be published between 1 January 2010 and 31 December 2020. These reports must also describe and highlight the enablers, barriers, and perceptions related to the sodium or salt reduction amongst the people, along with the steps undertaken by the policymakers or out-of-home sectors for implementing these steps. On the other hand, the studies that were not original editorials, book chapters, research articles, reviews, opinions, and commentaries or did not include new information and knowledge were not included in this review. Moreover, the studies that presented only summaries of earlier reports were not included in the review.

Perceived barriers are defined as a person's estimation of the level of challenge of social, personal, environmental, and economic obstacles to a specified behavior or their desired goal status on that behavior [20]. While, enablers are defined as the one that enables another to achieve an end in salt reduction strategies [3].

The search strategy used in this study was a combination of various keywords such as (Barriers OR enablers OR perceptions OR facilitators) AND (salt OR sodium reduction)) AND (out-of-home OR street OR restaurants OR cafeteria OR work place OR food industries). The synonyms and keywords generated after using the search terms are presented in Table 1.

Table 1. List of keywords and synonyms generated as search terms.

\begin{tabular}{ccccc}
\hline Barriers & Enablers & Perception & Salt Reduction & Out-of-Home \\
\hline limitation & motivate & view & sodium reduction & street \\
difficulty & promote & attitude & salt reduction & cafeteria \\
restriction & help & mindset & & work place \\
drawback & ease & willingness & & food industries \\
& aid & readiness & & \\
& policymakers & & & \\
\hline
\end{tabular}

The search strategy was implemented on different databases such as Google Scholar, Ebscohost, MEDLINE (PubMed), Ovid, and Cochrane Library. After using the inclusion and exclusion criteria, the search yielded 440 studies, out of which 65 articles (three qualitative and 62 quantitative studies) fulfilled all the criteria. Figure 1 presents the flow chart diagram implemented in the study. 
Identification of studies via databases and registers

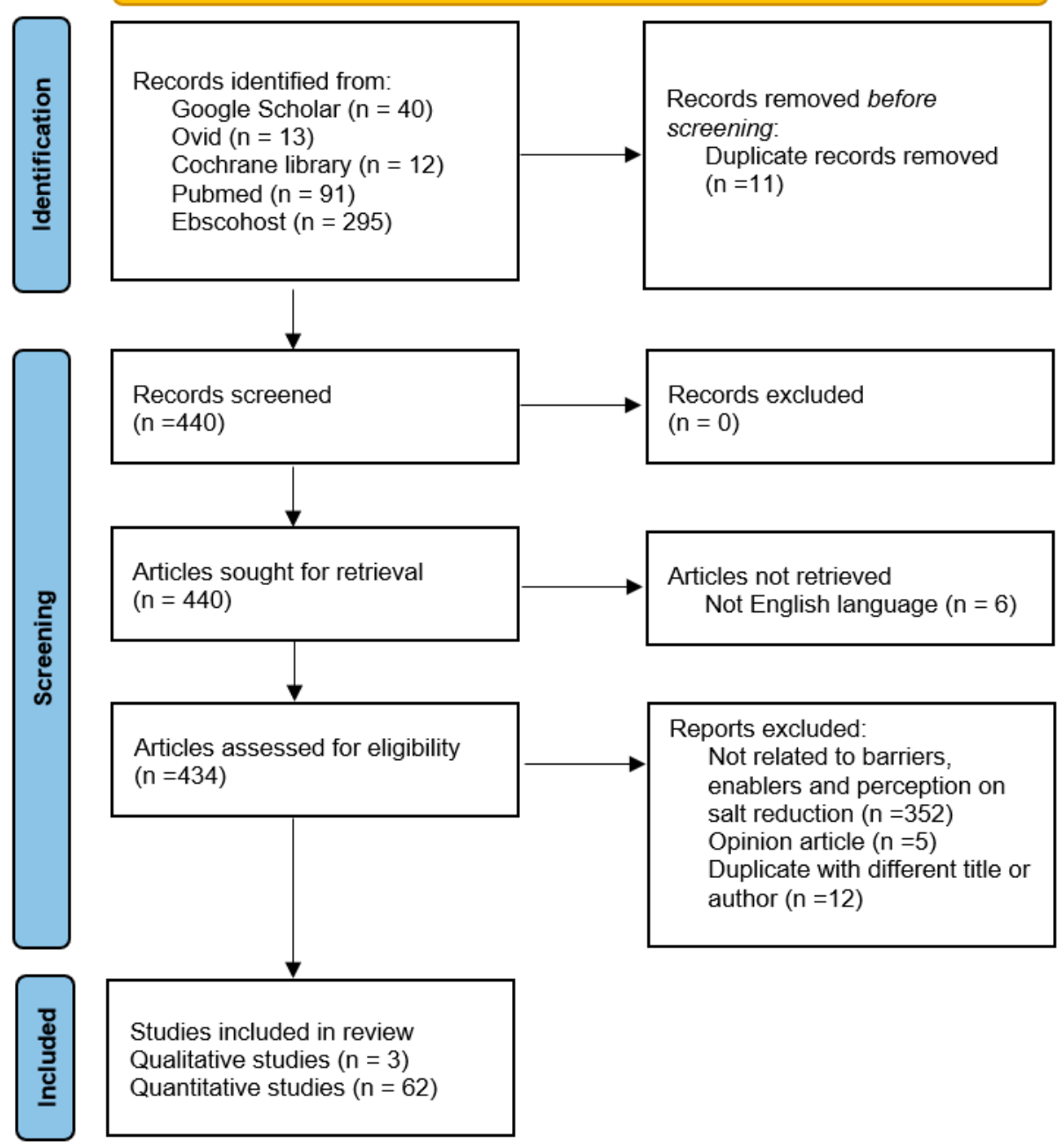

Figure 1. PRISMA-scoping review flow chart of included and excluded studies.

\subsection{Extraction and Analysis}

Table 2 presents a summary of the study characteristics included in the review. Thereafter, the researchers extracted and tabulated each abstract and full text of the final 65 studies included after the final analysis, for highlighting the year, survey, country, study design, participants, methodologies, results, and conclusions (Supplementary Materials Table S1). We analyzed every study for categorizing the studies into three major themes, i.e., barriers, enablers, and perceptions. 
Table 2. Summary of studies' characteristics.

\begin{tabular}{|c|c|c|c|c|c|c|}
\hline No. & $\begin{array}{l}\text { Research } \\
\text { Method }\end{array}$ & Study Design & Country & Study Year & Study Population & References \\
\hline \multirow[b]{3}{*}{1.} & \multirow[b]{3}{*}{ Qualitative } & \multirow[b]{3}{*}{$\begin{array}{l}\text { Focus group } \\
\text { discussions and } \\
\text { in-depth } \\
\text { interviews }\end{array}$} & USA & 2009 & $\begin{array}{l}\text { Policy makers (30 key informant } \\
\text { interviews from the County of Los Angeles } \\
\text { government departments) }\end{array}$ & [20] \\
\hline & & & South Korea & 2014 & 25 catering operators & [21] \\
\hline & & & India & Not stated & $\begin{array}{l}\text { The central and state governments }(\mathrm{n}=4) \text {; } \\
\text { the India Office and the South East Asia } \\
\text { Regional Office of the World Health } \\
\text { Organization }(\mathrm{n}=5) \text {; the Indian Council of } \\
\text { Medical Research }(\mathrm{n}=2) \text {; the World Bank } \\
(\mathrm{n}=1) \text {; food manufacturers }(\mathrm{n}=6) \text {; the } \\
\text { academia }(\mathrm{n}=10) ; \text { the National Institute of } \\
\text { Nutrition }(\text { NIN) }(\mathrm{n}=3) \text {; the civil society } \\
(\mathrm{n}=4) \text {; community members }(\mathrm{n}=7) \text { from } \\
\text { the urban and rural areas }\end{array}$ & [22] \\
\hline \multirow{19}{*}{2} & \multirow{19}{*}{ Quantitative } & \multirow{17}{*}{ Intervention } & Global & 2014-2017 & & {$[4,5,23-25]$} \\
\hline & & & USA & 2013 & & [26] \\
\hline & & & Africa & 2014-2015 & & {$[27,28]$} \\
\hline & & & Europe & 2015 & & [29] \\
\hline & & & Australia & 2015 & & [30] \\
\hline & & & China & 2018 & & [31] \\
\hline & & & $\begin{array}{l}\text { Eastern } \\
\text { Mediterranean } \\
\text { region }\end{array}$ & 2020 & & [32] \\
\hline & & & \multirow{3}{*}{ Europe } & 2012 & $\begin{array}{l}155 \text { school children aged } 10-12 \text { years old) } \\
\text { randomized equally to control and } \\
\text { intervention groups }\end{array}$ & [33] \\
\hline & & & & 2013 & $\begin{array}{l}\text { Intervention market survey (nine types of } \\
\text { partially baked, reduced-salt breads) } \\
\text { randomized equally }\end{array}$ & [34] \\
\hline & & & & 2015-2016 & $\begin{array}{l}371 \text { employees from work organization } \\
\text { aged } 20 \text { to } 65 \text { years (128 intervention, } \\
13 \text { control, and } 230 \text { non-participants) }\end{array}$ & [35] \\
\hline & & & Brazil & 2011 & $\begin{array}{l}206 \text { hypertensive patients aged } 20 \text { and } \\
\text { above randomized into } 101 \text { control and } \\
105 \text { intervention participants [36] }\end{array}$ & {$[36,37]$} \\
\hline & & & Canada & 2011 & $\begin{array}{l}987 \text { with or without hypertension public } \\
\text { randomized into four mock packages }\end{array}$ & [38] \\
\hline & & & \multirow[t]{2}{*}{ USA } & $\begin{array}{c}2010[39] \\
2014[40] \\
2013-2015[41]\end{array}$ & $\begin{array}{l}\text { Implementation of programme }[39,40] \\
21 \text { organizations including seven hospitals, } \\
\text { eight YMCA branches, four community } \\
\text { health centers, and two organization that } \\
\text { served individuals experiencing } \\
\text { homelessness [41] }\end{array}$ & [39-41] \\
\hline & & & & 2019 & $\begin{array}{l}\text { Intervention of sodium reduction laws } \\
\text { from all } 50 \text { states }\end{array}$ & [42] \\
\hline & & & Australia & 2011-2014 & $\begin{array}{l}572 \text { intervention participants aged } 20 \text { years } \\
\text { and above }\end{array}$ & [43] \\
\hline & & & Japan & 2015 & $\begin{array}{l}35 \text { housewives aged } 40 \text { years and above } \\
\text { and } 33 \text { family members aged } 20 \text { years and } \\
\text { above randomized into } 32 \text { control and } \\
36 \text { intervention participants }\end{array}$ & [44] \\
\hline & & & Korea & 2019 & $\begin{array}{l}\text { Policy makers } \\
\end{array}$ & [45] \\
\hline & & \multirow{2}{*}{ Retrospective } & Australia & $\begin{array}{l}2008-2011[46] \\
2018[47]\end{array}$ & $\begin{array}{c}107 \text { ready meal products } \\
\text { in 2008, } 313 \text { in 2009, } 219 \text { in 2010, } \\
\text { and } 265 \text { in 2011 [46] } \\
\text { Retrospectively applied Impact of } \\
\text { Translational health research (FAIT) } \\
\text { methods [47] } \\
\end{array}$ & {$[46,47]$} \\
\hline & & & USA & 2009-2014 & $\begin{array}{l}\text { Retrospective assessed target achievement } \\
\text { and change in sales-weighted mean } \\
\text { sodium density in top-selling products in } \\
61 \text { food categories in } 2009(\mathrm{n}=6336), 2012 \\
(\mathrm{n}=6898) \text {, and } 2014(\mathrm{n}=7396)\end{array}$ & [48] \\
\hline
\end{tabular}


Table 2. Cont.

\begin{tabular}{|c|c|c|c|c|c|c|}
\hline No. & $\begin{array}{l}\text { Research } \\
\text { Method }\end{array}$ & Study Design & Country & Study Year & Study Population & References \\
\hline & & \multirow{16}{*}{ Cross sectional } & Europe & $\begin{array}{l}2009[49] \\
2008[50]\end{array}$ & $\begin{array}{c}31 \text { restaurant catering operators [49] } \\
215 \text { restaurants ( } 140 \text { and } 75 \text { from Wirral and } \\
\text { Liverpool City Councils, respectively) [50] }\end{array}$ & {$[49,50]$} \\
\hline & & & & $\begin{array}{c}2014[51,52] \\
2011-2015[53]\end{array}$ & $\begin{array}{c}6348 \text { food products [51] } \\
501 \text { public consumers (aged } 18 \text { years } \\
\text { and above) [52] } \\
5759 \text { prepacked foods [53] }\end{array}$ & [51-53] \\
\hline & & & Australia & $\begin{array}{c}2010[54] \\
2015[55-57]\end{array}$ & $\begin{array}{l}907 \text { McDonald's and Subway lunchtime } \\
\text { customers (aged 16-84 years) [54] } \\
338 \text { participants aged } 18-65 \text { years [55] } \\
2559 \text { Victorian adults aged } \\
18-65 \text { years [56] } \\
479 \text { adults aged } 18-64 \text { years [57] }\end{array}$ & [54-57] \\
\hline & & & & 2014 & 1153 soup products & [58] \\
\hline & & & South Korea & $\begin{array}{l}2013[59] \\
2014[60]\end{array}$ & $\begin{array}{c}257 \text { females aged } 25 \text { to } 49 \text { years [59] } \\
738 \text { consumers aged } 18 \text { years and above }\end{array}$ & {$[59,60]$} \\
\hline & & & & $\begin{array}{l}2014[61] \\
2018[62]\end{array}$ & $\begin{array}{c}104 \text { food service personnel } \\
\text { working at } 17 \text { worksite cafeterias aged } \\
18 \text { years and above [61] } \\
312 \text { restaurant managers and chefs [62] }\end{array}$ & {$[61,62]$} \\
\hline & & & USA & $2012-2013$ & 221 Chinese take-out restaurants & [63] \\
\hline & & & & $\begin{array}{l}2013-2014[64] \\
2011-2012[65]\end{array}$ & $\begin{array}{l}450 \text { adults aged } 18 \text { years and above [64] } \\
2948 \text { children aged } 2-18 \text { years and } \\
4878 \text { adults aged }>18 \text { years [65] }\end{array}$ & {$[64,65]$} \\
\hline & & & Greece & 2011 & 3609 Greek adults aged over 25 years & [66] \\
\hline & & & Canada & $2011[67]$ & $\begin{array}{c}1013 \text { individuals aged } 18 \text { years and } \\
\text { above [67] } 27 \text { healthcare professionals [68] }\end{array}$ & {$[67,68]$} \\
\hline & & & Mongolia & 2010 & 1027 residents aged 25 to 64 years & [69] \\
\hline & & & Vietnam & 2013-2014 & 513 participants aged 25 to 64 years & [70] \\
\hline & & & Brazil & 2011-2013 & 21 food categories & [71] \\
\hline & & & Japan & 2013 & 267 school adolescents aged 12 to 18 years & [72] \\
\hline & & & Vanuatu & 2016-2017 & $\begin{array}{l}753 \text { participants aged between } 18 \text { and } \\
69 \text { years from rural and urban communities }\end{array}$ & [73] \\
\hline & & & $\begin{array}{l}\text { Latin America } \\
\text { China }\end{array}$ & 2015-2016 & $\begin{array}{l}\text { This study examined sodium levels in } \\
12 \text { categories of packaged foods }(n=16,357) \\
\text { sold in } 14 \text { Latin America countries }\end{array}$ & [74] \\
\hline & & & Netherlands & 2006-2015 & $\begin{array}{l}\text { The study population were, } \mathrm{n}=317(2006) \\
\mathrm{n}=342(2010), \mathrm{n}=289(2015) \text { in Netherlands }\end{array}$ & {$[75,76]$} \\
\hline & & & & $2007-2010$ & Dutch National Food Consumption Survey & [76] \\
\hline & & \multirow{3}{*}{$\begin{array}{l}\text { Projection } \\
\text { Modelling } \\
\text { approach }\end{array}$} & China & $\begin{array}{l}2019[75] \\
2016[76]\end{array}$ & & {$[77,78]$} \\
\hline & & & Netherlands & 2016 & & [79-81] \\
\hline & & & USA & 2013 & & [82] \\
\hline
\end{tabular}

Note: USA: United States of America.

\section{Results}

Table 3 summarizes the findings related to barriers, enablers, and perceptions of dietary salt reduction in the out-of-home sectors. 
Table 3. Summary of the papers related to barriers, enablers, and perceptions of dietary salt reduction in the out-ofhome sectors.

\begin{tabular}{|c|c|c|c|}
\hline & Study (Location) & Findings & References \\
\hline \multirow{5}{*}{$\begin{array}{l}\text { Barriers } \\
\text { Lack of menu and food } \\
\text { variabilities }\end{array}$} & & & \\
\hline & Gase et al. 2011 (USA) & Costs and unavailability of low-sodium foods & [20] \\
\hline & $\begin{array}{l}\text { Jaworowska et al. } 2012 \text { (UK) } \\
\text { Lee et al. } 2015 \text { (Korea) } \\
\text { Lee and Park } 2016 \text { (Korea) }\end{array}$ & $\begin{array}{c}\text { Popular hot takeaway meals have alarming high salt content } \\
\text { Need diverse menus at worksite } \\
\text { Lack of various delicious low sodium menus }\end{array}$ & $\begin{array}{l}{[50]} \\
{[60]} \\
{[61]}\end{array}$ \\
\hline & Ahn et al. 2019 (Korea) & $\begin{array}{c}\text { Maintaining taste and hindering the cooking process were } \\
\text { the main barriers to reduce sodium use }\end{array}$ & {$[62]$} \\
\hline & Dunford et al. 2020 (USA) & $\begin{array}{l}\text { The majority of sodium sources available in the market are } \\
\text { from packaged and processed food }\end{array}$ & [65] \\
\hline \multirow[t]{2}{*}{$\begin{array}{l}\text { Lack of technical expertise for } \\
\text { reformulation }\end{array}$} & Gase et al. 2011 (USA) & $\begin{array}{l}\text { Lack of knowledge and experience in operationalizing } \\
\text { sodium standards }\end{array}$ & {$[20]$} \\
\hline & Maalouf et al. 2013 (USA) & No comprehensive sodium content data in restaurant foods & [26] \\
\hline $\begin{array}{l}\text { Lack of technical skills for } \\
\text { cooking }\end{array}$ & Gase et al. 2011 (USA) & $\begin{array}{l}\text { Features of food service settings including their existing food } \\
\text { standards, other nutritional mandates, the populations they } \\
\text { serve, and current contracts }\end{array}$ & [20] \\
\hline \multirow{5}{*}{$\begin{array}{l}\text { Profit loss due to salt reduced } \\
\text { foods }\end{array}$} & Kloss et al. 2015 (Europe) & $\begin{array}{c}\text { Food safety issues, consumer acceptance concerns, cost } \\
\text { concerns and complications arising from the use of sodium } \\
\text { alternatives }\end{array}$ & [29] \\
\hline & Lee and Park 2016 (Korea) & $\begin{array}{c}\text { Limited methods of sodium-reduced cooking in worksite } \\
\text { cafeteria }\end{array}$ & {$[61]$} \\
\hline & Grime et al. 2017 (Australia) & No low salt foods available-eating out & [56] \\
\hline & Park et al. 2016 (Korea) & $\begin{array}{c}\text { Environmental factor such as pressure to maintain profit } \\
\text { margins }\end{array}$ & {$[21]$} \\
\hline & Gupta et al. 2018 (India) & Decreased sales due to salt reduction & {$[22]$} \\
\hline \multirow[t]{7}{*}{ Others } & Gase et al. 2011 (USA) & $\begin{array}{l}\text { Complexity of food service arrangements, lack of consumer } \\
\text { demand for low-sodium foods, undesirable taste of } \\
\text { low-sodium foods, preference for prepackaged products, and } \\
\text { existing multiyear contracts that are difficult to change }\end{array}$ & [20] \\
\hline & $\begin{array}{l}\text { Christoforou et al. } 2013 \\
\text { (Australia) }\end{array}$ & $\begin{array}{c}\text { Failure of voluntary industry efforts suggest a regulated } \\
\text { approach for ready meal products }\end{array}$ & [46] \\
\hline & Kloss et al. 2015 (Europe) & Limited motivation among food manufacturers & [29] \\
\hline & Curtis et al. 2016 (USA) & Industry slow progress & [48] \\
\hline & Inguglia et al. 2017 & $\begin{array}{l}\text { Microbial safety in low sodium meat products } \\
\text { Social and cultural beliefs, a large unorganized food retail }\end{array}$ & [25] \\
\hline & Gupta et al. 2018 (India) & $\begin{array}{l}\text { sector, and the lack of proper implementation of even } \\
\text { existing food policy }\end{array}$ & [22] \\
\hline & $\begin{array}{l}\text { Ahn et al. (2019) } \\
\text { Korean }\end{array}$ & $\begin{array}{l}\text { Purchasing experience after comparing sodium content in the } \\
\text { nutritional labeling }\end{array}$ & [62] \\
\hline \multirow{4}{*}{$\begin{array}{l}\text { Enablers } \\
\text { Training }\end{array}$} & & & \\
\hline & Ma et al. 2014 (USA) & $\begin{array}{l}\text { Training in food preparations, procurement and marketing } \\
\text { Skills and techniques related to measuring sodium content }\end{array}$ & [63] \\
\hline & Park et al. 2016 (Korea) & $\begin{array}{c}\text { and preparing reduced sodium meal (RSM) were } \\
\text { emphasized by the interviewees }\end{array}$ & [21] \\
\hline & Land et al. 2016 (Australia) & Good knowledge & [43] \\
\hline \multirow[t]{7}{*}{ Salt substitute } & Cotter et al. 2013 (Portugal) & Using herbs and spices & [33] \\
\hline & Land et al. 2016 (Australia) & Using substitutes & [43] \\
\hline & Quilez et al. 2016 (Spain) & Replacing salt with potassium citrate in bread & [34] \\
\hline & $\begin{array}{l}\text { Van Buren et al. } 2016 \\
\text { (Netherlands) }\end{array}$ & $\begin{array}{l}\text { Replacement of sodium chloride by potassium chloride, } \\
\text { particularly in key contributing product groups }\end{array}$ & {$[79]$} \\
\hline & Johnson et al. 2017 (Global) & Use of low sodium salt substitutes & [24] \\
\hline & Brooks et al. 2017 (USA) & Increase availability of lower-sodium products & [41] \\
\hline & Lacey et al. (2018) (Ontario) & $\begin{array}{l}\text { Lower-sodium foods, increased availability of pre-packaged } \\
\text { lower-sodium products }\end{array}$ & {$[68]$} \\
\hline \multirow[t]{7}{*}{ Gradual reduction of salt } & Coxson et al. 2013 (USA) & A gradual reduction in dietary sodium & [82] \\
\hline & Losby et al. 2014 (USA) & Gradual and voluntary reduction of sodium content & {$[40]$} \\
\hline & Curtis et al. 2016 (USA) & National target setting (voluntary target) & [48] \\
\hline & Johnson et al. 2017 (Global) & Specific sodium target & [24] \\
\hline & Levi et al. 2018 (Australia) & $\begin{array}{l}\text { A } 6 \% \text { reduction in sodium levels in soups overall was found } \\
\text { from } 2011 \text { to } 2014\end{array}$ & {$[58]$} \\
\hline & Yang et al. 2019 (China) & $\begin{array}{l}\text { Stages of salt reduction in food industry } \\
\text { South Korea implemented its National Plan to Reduce }\end{array}$ & [77] \\
\hline & Park et al. 2020 (Korea) & $\begin{array}{l}\text { Sodium Intake, with a goal of reducing population sodium } \\
\text { consumption by } 20 \% \text {, to } 3900 \mathrm{mg} / \text { day, by } 2020\end{array}$ & [45] \\
\hline \multirow[t]{5}{*}{ Intervention } & $\begin{array}{l}\text { Christoforou et al. } 2013 \\
\text { (Australia) }\end{array}$ & Reformulation & {$[46]$} \\
\hline & Coxson et al. 2013 (USA) & $\begin{array}{l}\text { Range of proposed public health intervention } \\
\text { Weekly lessons on danger of high salt intake, (theory), }\end{array}$ & [82] \\
\hline & Cotter et al. 2013 (Portugal) & $\begin{array}{c}\text { practical lessons in school garden of planting and collection } \\
\text { of herbs for salt substitution at home }\end{array}$ & [33] \\
\hline & Lima et al. 2013 (Brazil) & Feasible dietary approach & [36] \\
\hline & Wong et al. 2013 (Canada) & $\begin{array}{ll}\text { - } & \text { Sodium claim } \\
\text { - } & \text { Active education program of sodium reduced cooking }\end{array}$ & [38] \\
\hline
\end{tabular}




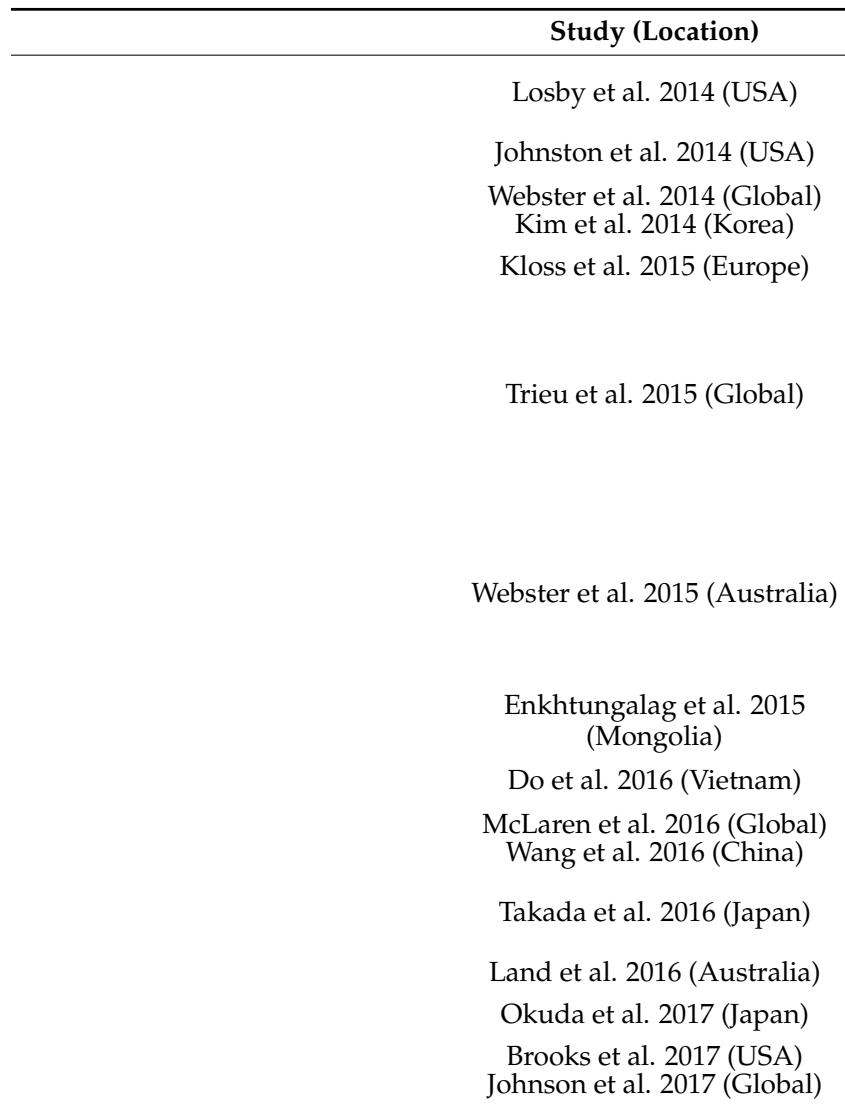

Table 3. Cont.
Zhang et al. 2018 (China)

Food analysis studies and salt intake measurement

Gupta et al. 2018 (India) Yang et al. 2019 (China)

Sloan et al. 2020 (USA) Mediterranean Region)

Product substitutions, recipe modifications, and cooking

Product substitutions, recipe modifications, and cooking from scratch

A social marketing approach was used to educate consumers about the hidden sources of dietary sodium Legislation Labels influenced consumer satisfaction

Food reformulation efforts have been made in the bread, meat, dairy, and convenience foods industries

References

[40]

[39]

- Reformulation with sodium content targets

- Consumer education

- $\quad$ Front-of-pack labelling

- Taxation of high-salt foods

- Public institution

- $\quad$ Drop Salt Campaign by NGOs and food industry to advocate the government to develop a national strategy to reduce salt

- Food reformulation

- Health Star rating front pack labelling

Pinch Salt intervention to reduce salt consumption among factory workers

COMBI intervention-effective in lowering salt intake and improving knowledge and behaviours Population level intervention

Population wide dietary salt reduction policies

Measure the difference in estimated daily salt intake by spot urine sampling of housewives and their family members 2 months after intervention between the groups Read labels

Home environment and salt-use behaviour intervention in secondary school

Increase availability of lower-sodium products Behavior change intervention

- $\quad$ AIS-Application Based Intervention Study using mobile application to reinforce and maintain lower salt intake

- RIS-Restaurant based Intervention Study for

Trieu et al. 2018 (Australia)

Doggui et al. 2020 (Eastern

Cotter et al. 2013 (Portugal)

Antoniolli et al. 2014 (Australia)

Losby et al. 2014 (USA)

Korosec et al. 2014 (Slovenia)

Enkhtungalag et al. 2015 (Mongolia)

Johnson et al. 2017

Nilson et al. 2017 (Brazil)

Pravst et al. 2017 (Slovenia)

Arcand et al. 2019 (Latin America)

Temme et al. (2017)

Others

Cotter et al. 2013 (Portugal)

Antoniolli et al. 2014 (Australia)

Ma et al. 2014 (USA) consumers, cooks, and restaurant managers

- HIS-Housewife Intervention Study for family chef

- CIS-Comprehensive Intervention Study for evaluating all interventions

The development and adoption of the National

Multi-Sectoral Action Plan
Components chosen in an intervention is important

Vigorous advancements of salt reduction actions

Laws: Labels, workplace, vending machines

Mandatory regulatory measures for universal salt iodization

$24 \mathrm{~h}$ urinary sodium excretion analysis

Sodium and saturated fat contents were calculated from company websites

Sodium nutrient analysis

Market leaders have lower salt content through comparison of the category average sodium content of prepackaged foods

Salt in tea contribute $30 \%$ of daily salt intake

Spot or $24 \mathrm{~h}$ urinary sodium salt intake measurement

Monitoring sodium content of food

Sales weighted sodium content

Sodium content in packed foods and positive impact of menu labeling

The salt content of bread, certain sauces, soups, potato crisps, processed legumes and vegetables have been reduced over the period 2011-2016 in Netherlands. However, median salt intake in 2006 and 2015 remained well above the

recommended intake of $6 \mathrm{~g}$
Blood pressure measurement

Nutritionally promoted fast foods may contain less sodium when selected

Customer demand maintained strategies and support 
Table 3. Cont.

\begin{tabular}{c}
\hline Study (Location) \\
\hline $\begin{array}{c}\text { Losby et al. } 2014 \\
\text { (USA) }\end{array}$ \\
Sookram et al. 2015 (Africa) \\
McLaren et al. 2016 \\
Curtis et al. 2016 (USA) \\
Park et al. 2016 (Korea)
\end{tabular}

Inguglia et al. 2017 (Global)

Lacey et al. 2018 (Ontario)

Gupta et al. 2018 (India)

Ahn et al. 2019 (Korea)

Hendriksen et al. (2015a)

Hendriksen et al. (2015b)

Hendriksen et al. (2017)

\section{Perceptions}

High salt is bad for health

Low salt food was recognized as tasteless

Individual or organizational characteristics
Mallia et al. 2012 (Europe)

Kim et al. 2014 (Korea)

Mezue et al. 2014 (Nigeria)

Ma et al. 2014 (USA)

Enkhtungalag et al. 2015 (Mongolia)

Trieu et al. 2018 (Australia)

Sparks et al. 2019 (Vanuatu)

Ahn et al. 2019 (Korea)

Gupta et al. 2018 (India)

Lacey et al. 2018 (Ontario)

Mallia et al. 2012 (Europe)

Kim et al. 2014 (Korea)

Losby et al. 2014 (USA)

Marakis et al. 2014 (Greece)

Enkhtungalag et al. 2015 (Mongolia)

Regan et al. 2016 (Ireland)
Identifying partners with shared experience and common goals

Working towards sustainable sodium reduction

Overview of WHO supported interventions on salt intake reduction among Member States of the African Multicomponent intervention incorporating product reformulation among men

Monitoring through partnership of local as well as state and national health organizations

Key stakeholders' psychosocial characteristics and environment factors

High pressure processing and power ultrasound, seem to be promising to ensure microbiological safety in low-sodium meat products

Group purchasing organizations, government prioritizing, and providing support and resources. Improved tastes of lower-sodium foods

Most of the stakeholders were in alignment with the need for a salt reduction programme in India to prevent and control hypertension and related cardiovascular diseases

Supportive social environment, improving dietary habits of eating high salt foods

Predictive study using population health modelling tool showed that reduction of salt intake to $5 \mathrm{~g}$ per day is expected to substantially reduce the burden of cardiovascular disease and mortality in several European countries Modification of food composition or by alteration of

behaviour may substantially reduce the median sodium intake using two scenarios from the National Food Consumption Survey 2011.

Different health impact model assessment from seven population health impact models may affect the health impact estimate, however, the estimated impact of salt reduction was substantial in all of the models used, emphasizing the need for public health actions

$99 \%$ of the respondents were aware which foods are low or high in salt

Consumers' knowledge of the relationship between diets high in sodium and an increased risk of developing previously reported sodium-related diseases Plan for a population-wide salt reduction strategy

Lack of knowledge on the danger of high salt intake

Mongolia has one of the highest rates of stroke, high salt intake from tea $(30 \%)$

The proportion who understood the adverse effects of salt

\[ (+9.0 \%, p=0.049) \]
Total of $83 \%$ of participants agreed that too much salt could cause health problems

Knowledge edge of the recommendation of salt, difference between sodium and salt

Participant perceived that reduced salt will make food not tasty

$37 \%$ believe that the patient would decrease with sodium reduction

$90 \%$ of the participants added salt to dishes to enhance

flavour and improve taste
Current consumer knowledge on the sodium content in food products was high

Understanding the complexity of the meal's system for older adults

Gender (more women added salt during cooking, less on the plate compared to men, more women believed that salt

added during cooking was the main source of salt in the diet). For age, participants aged 25-34,35-44, and 45-54 years old had better knowledge of the harmful effects of salt on health compared with 55 years and above

Most participants knew that salt was bad for health, few

were taking efforts to reduce intake, and many were consuming highly salty meals and tea

A series of multiple regressions revealed that individual attitudes and beliefs related to health and salt were stronger or knowledge

Acceptance of the reduced salt bread predictors of support than sociodemographic factors, lifestyle

References

Quilez et al. 2016 (Spain) 
Table 3. Cont.

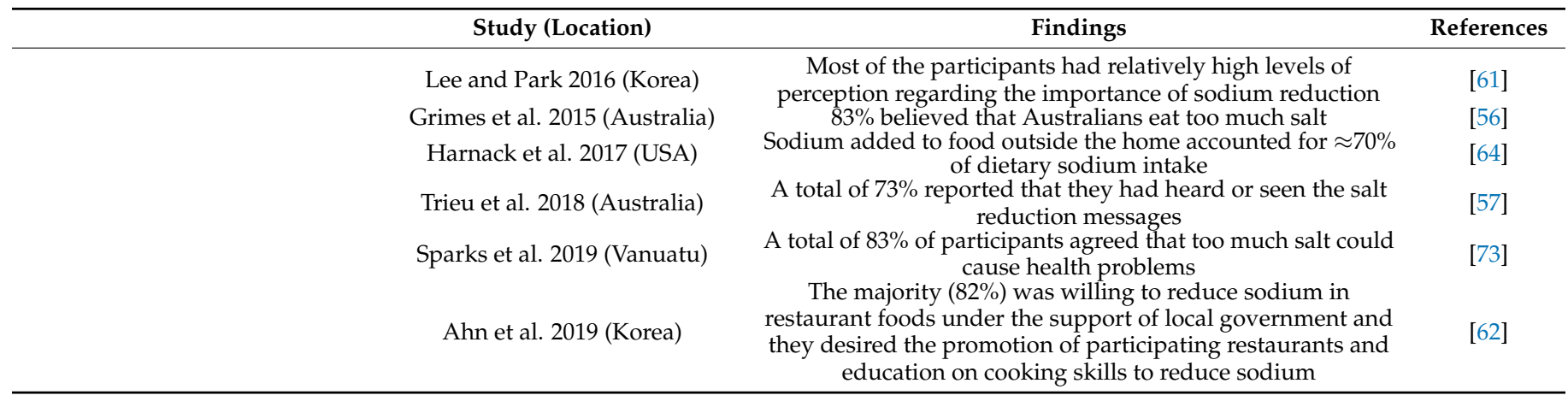

Note: UK: United Kingdom; USA: United States of America.

\subsection{Barriers of Dietary Salt Reduction in the Out-of-Home Sectors}

The findings for the barriers which prevented salt reduction in the out-of-home sectors included the lack of menu and food variabilities, lack of technical skills for cooking, profit loss due to salt-reduced foods, lack of technical expertise for reformulation, and other factors as listed in Table 3.

\subsection{Enablers of Dietary Salt Reduction in the Out-of-Home Sectors}

Enablers are described as factors that help in the implementation of salt reduction programmes, strategies, initiatives, and interventions for various out-of-home sectors. Enabling factors that encouraged a salt reduction in the out-of-home sectors included the salt reduction intervention program, food analysis studies, salt substitute accessibility, gradual reduction of salt approach, training availability, and other factors which were categorized separately as listed in Table 3.

\subsection{Perceptions of Dietary Salt Intake in the Out-of-Home Sectors}

The perceptions of people on salt intake in out-of-home sectors are shown in Table 3. These included the negative effects of a high salt diet, low salt foods recognized as tasteless, and individual or organizational characteristics effects in salt reduction.

\section{Discussion}

The out-of-home sectors that have been considered in this review include catering operators, food industries, school children, workplace organizations, and food industries. Food industries worked hand-in-hand with the policymakers and implemented interventions for decreasing the total salt content. The majority of the interventions which targeted the foodservice settings and work places were implemented in the USA, South Korea, and China $[21,31,63]$.

\subsection{Dietary Salt Intake and Sources}

The studies carried out in the USA showed that salt was added to the diet from different packaged/non-packaged foods or foods sourced from out-of-home settings. This was responsible for a total of $67-70 \%$ of the salt intake among the population $[64,65]$. Similarly, studies conducted in the European Union indicated that the people had a higher salt intake, wherein $75-80 \%$ of the salt intake was due to the consumption of processed foods, $10-15 \%$ of the salt was added during the cooking process or at the table, while $5-10 \%$ of the salt was naturally present in different food items. However, in developing and LMIC countries, the salt that was used for seasoning played a vital role [29,83]. A recent study showed that the intake of salt was increasing amongst the Chinese population [78]. A majority of the processed foods that were available in the Chinese local supermarkets were high in salt content [84]. 
This scoping review noted that a majority of the countries such as the UK, USA, Australia, European countries, South Korea, and Brazil have set a few national voluntary targets $[45,48]$. This was implemented after many reformulation efforts were carried out in the food products such as meat, dairy products, bread, and soups $[29,46,58]$. This was considered a very effective intervention as it helped in averting $0.7-1.9$ million deaths in 10 years using a modelling approach, as proposed by Coxson et al. (2013) [82]. Moreover, mandatory salt reduction targets using legislation were achieved in South Africa for many food products [28].

\subsection{Barriers for Dietary Salt Reduction}

A lack of availability of low salt foods, lesser food choices or menu variability and incomprehensive salt data were regarded as major barriers that affected the out-of-home sectors in this review. These issues were attributed to a lack of technical skills for reformulation and cooking low salt foods [26]. An absence of food analysis techniques for measuring the salt concentration in the foods was also an issue.

Issues related to the lack of technical skills in preparing or producing low salt foods have to be resolved as they can lead to food safety problems, concerns regarding consumer acceptance, higher costs, and complications arising due to the use of various sodium alternatives. This can be a factor that could demotivate the food manufacturers in European countries [29]. In addition, several environmental factors such as pressure for maintaining profit margins and fear of decreased sales from the industrial sectors act as barriers that prevent the production of low salt foods [21,22,47]. Many of the barriers listed in this scoping review are dependent on capacity building and can easily be eliminated through proper training, intervention or education as highlighted in the Enablers findings.

\subsection{Enablers for Dietary Salt Reduction}

The effective intervention strategies include product substitutions [25], recipe modification [40], social marketing approach [39], comparing the salt concentration in different pre-packaged foods based on the available data such as sales-weighted sodium concentration and sodium data presented on the Nutrition Facts panel provided in the restaurants and point of purchase, offering low salt foods and encouraging the consumers to buy low sodium food products.

Salt substitutes that are used for reformulating the food products such as potassium chloride can be used for replacing the sodium chloride salts in various products [33,79]. Additionally, potassium citrate can be used for replacing salt in different types of bread [34] or herbs can be used as a salt substitute while cooking foods at home [33]. Salt substitutes such as potassium chloride could reduce dietary sodium intake and cause an increase in dietary potassium results in the decreased incidence of hypertension [79]. Reformulating food products to lower sodium levels using potassium chloride may actually result in positive health effects in the general population [79]. The limited availability of different low salt food products in the supermarkets, cafeteria, work-places, vending machines, and kiosks is attributed to the inability of the food manufacturing companies in reformulating their food products [48] or a lack of technical skills by the workers and chefs. Hence, the policymakers need to develop policies to reformulate the foods using various salt substitutes [41] and provide technical training to the different personnel with regards to food preparation, food procurement or marketing [63]. In one wholesale survey study, the researchers noted that when people were offered nine types of low salt bread that were prepared using potassium citrate, they accepted the products and did not voice any complaints regarding the flavor changes. They further stated that the respondents were unaware of salt substitution and reduction [34]. This study indicated that it is possible to reduce the salt concentration in foods using appropriate salt substitutes, without altering the taste of the food.

For ensuring salt reduction, the policymakers have to carry out a food analysis study and update their databases to provide information related to the salt content in the packed 
foods or food acquired from out-of-home sectors to monitor and compare the salt targets and provide better food labels [74]. The salt concentrations can be measured after a $24 \mathrm{~h}$ urine analysis along with the blood pressure after 6 months of three educational interventions among 155 of 10-12 years old school children. This helps in determining if the salt reduction intervention is effective or not [33]. It is important to identify the partners having a shared experience and common objectives and who aim for a sustainable salt reduction [40].

Effective legislation is one of the salt reduction strategies that has been implemented in many countries such as South Africa, Argentina, Belgium, Bulgaria, Netherlands, Portugal, and Paraguay [23,75,85-87]. For instance, South Africa and Argentina have set the maximum total sodium levels for 13 and 18 categories of food products, respectively that started in 2013 [85,88]. The other countries have also implemented the legislation on salt reduction through the regulation by setting the maximum level of sodium content in food products such as breads, cheese, meat, and poultry $[75,86,87]$.

Appropriate training must be provided to the staff for food preparation, food procurement, and marketing [63]. It helped the employees improve their skills and learn new techniques for preparing low salt food such as in the Korean catering firms [21]. The staff should also be trained to improve their knowledge for reducing salt intake [43].

Other enabling factors which helped in reducing the salt intake included the maintenance of customer demands, implementation of effective strategies, and support. Monitoring and establishing a partnership between the state, local, and national health organizations is necessary [48]. The psychological characteristics of the stakeholders and environmental factors also play a vital role in decreasing salt intake. A supportive social setting helps in improving the dietary habits of the people who eat foods with a higher salt concentration [62].

\subsection{Perceptions on Dietary Salt Reduction}

A study by Ma et al. (2014) indicated that very few people in the USA are aware of the dangers of taking high salt-content foods and display a lack of knowledge regarding the salt content in the packaged food products [63]. This issue can be resolved by implementing education-based intervention strategies such as community awareness campaigns, schoolbased education, and media campaign regarding salt reduction [57].

Furthermore, individual and organizational characteristics play a vital role in salt intake. Mallia et al. (2012) conducted a survey that showed that $90 \%$ of the respondents added salt to their dishes for improving the flavor and taste of the foods [49]. With regards to gender, many of the women add salt to the foods during cooking compared to the men who add more salt to their food on the table. Moreover, many women believed that salt added during cooking was the major source of salt in their diet. The study indicated that the Greek adults aged from 25 to 34,35 to 44 , and 45 to 54 years had a better knowledge regarding the harmful effects of salt on their health in comparison to respondents above 55 years of age [66]. With regards to individual knowledge, one-third of the Australian adults $(32 \%)$ stated that they added salt to their plates on the table. Seventy three percent of the respondents stated that they had seen or heard the salt reduction messages [55]. Some of the factors which contributed to a higher salt intake included age and gender (which could not be modified), in addition to knowledge, attitude, and practices followed by the individuals that can be modified and improved by education $[7,89,90]$.

Very few studies were conducted in the LMICs, particularly in the South-East Asian regions. The cost-effectiveness of implementing salt reduction strategies in these countries was not reported. Hence, a detailed and comprehensive study needs to be carried out in the future. A majority of the barriers, enablers, and perceptions of the individuals highlighted in this scoping review can help the governments and policymakers in the LMIC regions for developing, implementing or monitoring the strategies and policies for reducing the salt intake among the people. 


\section{Conclusions}

This review defined the various barriers affecting the implementation of salt reduction strategies, which were (1) Lack of menu and food variabilities, (2) Lack of technical skills for cooking with lower salt, (3) Profit loss due to loss of sales, and (4) Lack of technical expertise for reformulation. The enablers themes are (1) Salt reduction intervention, (2) Food analysis studies and salt intake measurement, (3) Salt substitute accessibility, and (4) Gradual reduction of salt approach and Training availability. The perceptions themes are (1) Individual or organizational characteristics effects on salt intake, (2) Negative effects of high salt diet, and (3) Low salt food was recognized as tasteless. It was seen that the barriers, enablers, and perceptions regarding the dietary salt reduction in the out-of-home sectors were multifaceted. It is important to implement strategies, policies, and initiatives for addressing the barriers. For this purpose, a multisectoral collaboration from different stakeholders such as policymakers, food industries, catering operators, and food vendors is necessary to reduce the salt intake in the out-of-home sectors.

Supplementary Materials: The following are available online at https: / www.mdpi.com/article / 10.3390 /ijerph18158099/s1, Table S1. Barriers, enablers, and perceptions on dietary salt reduction in the out-of-home sectors.

Author Contributions: V.M. and S.S. conceived the study and design. All authors contributed to the development of the scoping strategy, design, methodology, and interpretation of results. V.M., Y.X.Y. and S.N.S. conducted the scoping review including screening and mapping with input from all other authors. All authors (V.M., Y.X.Y., S.S., Z.A.M., H.H., S.N.S., H.A.M., Y.C.C., M.K.B., F.J.H. and G.A.M.) have contributed in drafting and agreed to the final manuscript. All authors have read and agreed to the published version of the manuscript.

Funding: This review is supported as part of the Newton Fund Impact Scheme by the Medical Research Council on behalf of UK Research and Innovation in the UK and by the Malaysia IndustryGovernment Group for High Technology (MIGHT) (grant no. NN-2020-082, MR/V005847/1).

Institutional Review Board Statement: Not applicable.

Informed Consent Statement: Not applicable.

Data Availability Statement: All data are contained within this manuscript.

Acknowledgments: We would like to express our gratitude to all the authors for their involvement in this review.

Conflicts of Interest: V.M., S.S., H.H. and H.A.M. are unpaid members of the National Salt Reduction Study of Malaysia. F.J.H. is an unpaid member of Action on Salt, and World Action on Salt, Sugar and Health (WASSH). F.H. is partially funded by the National Institute for Health Research (NIHR) and the Medical Research Council (MRC). G.A.M. is the unpaid Chair of Action on Salt, Sugar and Health, WASSH and Blood Pressure UK. G.A.M. is partially funded by the National Institute for Health Research (NIHR) and the Medical Research Council (MRC). The other authors declare no conflict of interest.

\section{References}

1. Raj, S.E.; Tan, L.M.; Redzuan, A. Dietary salt intake: History, assessment, and benefit in hypertensive treatment. Asian J. Pharm. Clin. Res. 2016, 9, 39-42. [CrossRef]

2. Shahrir, S.N.; Abdul Manaf, M.R.; Mustapha, F.I.; Isa, M.Z. Critical review on dietary sodium reduction policies in Malaysia. Int. Food Res. J. 2019, 26, 33-40.

3. He, F.J.; MacGregor, G.A. Reducing population salt intake worldwide: From evidence to implementation. Prog. Cardiovasc. Dis. 2010, 52, 363-382. [CrossRef] [PubMed]

4. Trieu, K.; Neal, B.; Hawkes, C.; Dunford, E.; Campbell, N.; Rodriguez-Fernandez, R.; Legetic, B.; McLaren, L.; Barberio, A.; Webster, J. Salt reduction initiatives around the world-A systematic review of progress towards the global target. PLoS ONE 2015, 10, e0130247. [CrossRef]

5. McLaren, L.; Sumar, N.; Barberio, A.M.; Trieu, K.; Lorenzetti, D.L.; Tarasuk, V.; Webster, J.; Campbell, N.R.C. Population-level interventions in government jurisdictions for dietary sodium reduction. Cochrane Database Syst. Rev. 2016. [CrossRef]

6. Cappuccio, F.; Capewell, S. Facts, issues, and controversies in salt reduction for the prevention of cardiovascular disease. Funct. Food Rev. 2015, 7, 41-61. [CrossRef] 
7. Lallukka, T.; Laaksonen, M.; Rahkonen, O.; Roos, E.; Lahelma, E. Multiple socio-economic circumstances and healthy food habits. Eur. J. Clin. Nutr. 2007, 61, 701-710. [CrossRef]

8. Azizan, N.A.; Majid, H.A.; Nahar Mohamed, A.; Su, T.T. Improvement of nutritional intake for the low-income urban dwellers with hypertension in Malaysia. SAGE Open Med. 2020, 8, 2050312120960563. [CrossRef]

9. World Health Organization South East Asia. Salt Reduction in the Out of Home Sector. Available online: https: //cdn.who.int/media/docs/default-source/searo/healthy-diets/salt-reduction/salt-reduction-in-the-out-of-home-sector. pdf?sfvrsn=32a0eb40_3 (accessed on 5 April 2021).

10. Seguin, R.A.; Aggarwal, A.; Vermeylen, F.; Drewnowski, A. Consumption frequency of foods away from home linked with higher body mass index and lower fruit and vegetable intake among adults: A cross-sectional study. J. Environ. Public Health 2016, 2016, 3074241. [CrossRef]

11. Bezerra, I.N.; Curioni, C.; Sichieri, R. Association between eating out of home and body weight. Nutr. Rev. 2012, 70, 65-79. [CrossRef] [PubMed]

12. Kant, A.K.; Whitley, M.I.; Graubard, B.I. Away from home meals: Associations with biomarkers of chronic disease and dietary intake in American adults, NHANES 2005-2010. Int. J. Obes. 2015, 39, 820-827. [CrossRef] [PubMed]

13. National Health and Family Planning Commission of the PRC. 2014 Report on Chinese Resident's Chronic Disease and Nutrition; National Health and Family Planning Commission of the PRC: Beijing, China, 2015.

14. Lachat, C.; Nago, E.; Verstraeten, R.; Roberfroid, D.; Van Camp, J.; Kolsteren, P. Eating out of home and its association with dietary intake: A systematic review of the evidence. Obes. Rev. 2012, 13, 329-346. [CrossRef] [PubMed]

15. Jaworowska, A.; Blackham, T.M.; Long, R.; Taylor, C.; Ashton, M.; Stevenson, L.; Glynn Davies, I. Nutritional composition of takeaway food in the UK. Nutr. Food Sci. 2014, 44, 414-430. [CrossRef]

16. Murakami, K.; Sasaki, S.; Takahashi, Y.; Uenishi, K. Neighborhood restaurant availability and frequency of eating out in relation to dietary intake in young Japanese women. J. Nutr. Sci. Vitaminol. 2011, 57, 87-94. [CrossRef] [PubMed]

17. Arksey, H.; O'Malley, L. Scoping studies: Towards a methodological framework. Int. J. Soc. Res. Methodol. 2005, 8, 19-32. [CrossRef]

18. Levac, D.; Colquhoun, H.; O'Brien, K.K. Scoping studies: Advancing the methodology. Implement. Sci. 2010, 5, 69. [CrossRef]

19. Daudt, H.M.L.; van Mossel, C.; Scott, S.J. Enhancing the scoping study methodology: A large, inter-professional team's experience with Arksey and O'Malley's framework. BMC Med Res. Methodol. 2013, 13, 48. [CrossRef] [PubMed]

20. Gase, L.N.; Kuo, T.; Dunet, D.O.; Simon, P.A. Facilitators and barriers to implementing a local policy to reduce sodium consumption in the County of Los Angeles government, California, 2009. Prev. Chronic Dis. 2011, 8, A33.

21. Park, S.; Lee, J. 'When operating a cafeteria, sales come before nutrition'-Finding barriers and facilitators to serving reducedsodium meals in worksite cafeterias. Public Health Nutr. 2016, 19, 1506-1516. [CrossRef]

22. Gupta, P.; Mohan, S.; Johnson, C.; Garg, V.; Thout, S.R.; Shivashankar, R.; Krishnan, A.; Neal, B.; Prabhakaran, D. Stakeholders' perceptions regarding a salt reduction strategy for India: Findings from qualitative research. PLoS ONE 2018, 13, e0201707. [CrossRef]

23. Webster, J.; Trieu, K.; Dunford, E.; Hawkes, C. Target salt 2025: A global overview of national programs to encourage the food industry to reduce salt in foods. Nutrients 2014, 6, 3274-3287. [CrossRef] [PubMed]

24. Johnson, C.; Santos, J.A.; McKenzie, B.; Thout, S.R.; Trieu, K.; McLean, R.; Petersen, K.S.; Campbell, N.R.C.; Webster, J. The science of salt: A regularly updated systematic review of the implementation of salt reduction interventions (September 2016-February 2017). J. Clin. Hypertens. 2017, 19, 928-938. [CrossRef]

25. Inguglia, E.S.; Zhang, Z.; Tiwari, B.K.; Kerry, J.P.; Burgess, C.M. Salt reduction strategies in processed meat products-A review. Trends Food Sci. Technol. 2017, 59, 70-78. [CrossRef]

26. Maalouf, J.; Cogswell, M.E.; Gunn, J.P.; Curtis, C.J.; Rhodes, D.; Hoy, K.; Pehrsson, P.; Nickle, M.; Merritt, R. Monitoring the sodium content of restaurant foods: Public health challenges and opportunities. Am. J. Public Health 2013, 103, e21-e30. [CrossRef] [PubMed]

27. Mezue, K. The increasing burden of hypertension in Nigeria-Can a dietary salt reduction strategy change the trend? Perspect. Public Health 2014, 134, 346-352. [CrossRef]

28. Sookram, C.; Munodawafa, D.; Phori, P.M.; Varenne, B.; Alisalad, A. WHO's supported interventions on salt intake reduction in the sub-Saharan Africa region. Cardiovasc. Diagn. Ther. 2015, 5, 186-190. [CrossRef] [PubMed]

29. Kloss, L.; Meyer, J.D.; Graeve, L.; Vetter, W. Sodium intake and its reduction by food reformulation in the European Union-A review. NFS J. 2015, 1, 9-19. [CrossRef]

30. Webster, J.; Trieu, K.; Dunford, E.; Nowson, C.; Jolly, K.-A.; Greenland, R.; Reimers, J.; Bolam, B. Salt reduction in Australia: From advocacy to action. Cardiovasc. Diagn. Ther. 2015, 5, 207-218. [CrossRef] [PubMed]

31. Zhang, P.; He, F.J.; Li, Y.; Ma, J.; Wu, J.; Wang, H.; Li, Y.; Han, J.; Luo, R.; Wang, Y.; et al. Salt reduction in China: From evidence to action. Lancet 2018, 392, S29. [CrossRef]

32. Doggui, R.; Al-Jawaldeh, H.; Al-Jawaldeh, A. Trend of iodine status in the eastern Mediterranean region and impact of the universal salt iodization programs: A narrative review. Biol. Trace Elem. Res. 2020, 198, 390-402. [CrossRef]

33. Cotter, J.; Cotter, M.J.; Oliveira, P.; Cunha, P.; Polónia, J. Salt intake in children 10-12 years old and its modification by active working practices in a school garden. J. Hypertens. 2013, 31, 1966-1971. [CrossRef] 
34. Quilez, J.; Salas-Salvado, J. The feasibility and acceptability of reducing salt in partially baked bread: A Spanish case study. Public Health Nutr. 2016, 19, 983-987. [CrossRef]

35. Beer-Borst, S.; Hayoz, S.; Eisenblätter, J.; Jent, S.; Siegenthaler, S.; Strazzullo, P.; Luta, X. RE-AIM evaluation of a one-year trial of a combined educational and environmental workplace intervention to lower salt intake in Switzerland. Prev. Med. Rep. 2019, 16, 100982. [CrossRef]

36. Lima, S.T.; da Silva Nalin de Souza, B.; França, A.K.; Salgado Filho, N.; Sichieri, R. Dietary approach to hypertension based on low glycaemic index and principles of DASH (Dietary Approaches to Stop Hypertension): A randomised trial in a primary care service. Br. J. Nutr. 2013, 110, 1472-1479. [CrossRef]

37. Frantz, C.B.; Veiros, M.B.; Proença, R.P.d.C.; Sousa, A.A.d. Development of a method for controlling salt and sodium use during meal preparation for food services. Rev. Nutr. 2013, 26, 75-87. [CrossRef]

38. Wong, C.L.; Arcand, J.; Mendoza, J.; Henson, S.J.; Qi, Y.; Lou, W.; L'Abbé, M.R. Consumer attitudes and understanding of low-sodium claims on food: An analysis of healthy and hypertensive individuals. Am. J. Clin. Nutr. 2013, 97, 1288-1298. [CrossRef]

39. Johnston, Y.A.; McFadden, M.; Lamphere, M.; Buch, K.; Stark, B.; Salton, J.L. Working with grocers to reduce dietary sodium: Lessons learned from the Broome County Sodium Reduction in Communities pilot project. J. Public Health Manag. Pract. 2014, 20, S54-S58. [CrossRef]

40. Losby, J.L.; Patel, D.; Schuldt, J.; Hunt, G.S.; Stracuzzi, J.C.; Johnston, Y. Sodium-reduction strategies for meals prepared for older adults. J. Public Health Manag. Pract. 2014, 20, S23-S30. [CrossRef] [PubMed]

41. Brooks, C.J.; Barrett, J.; Daly, J.; Lee, R.; Blanding, N.; McHugh, A.; Williams, D.; Gortmaker, S. A community-level sodium reduction intervention, Boston, 2013-2015. Am. J. Public Health 2017, 107, 1951-1957. [CrossRef] [PubMed]

42. Sloan, A.A.; Keane, T.; Pettie, J.R.; Bhuiya, A.R.; Taylor, L.N.; Bates, M.; Bernard, S.; Akinleye, F.; Gilchrist, S. Mapping and analysis of US state and urban local sodium reduction laws. J. Public Health Manag. Pract. 2020, 26, S62-S70. [CrossRef] [PubMed]

43. Land, M.-A.; Wu, J.H.Y.; Selwyn, A.; Crino, M.; Woodward, M.; Chalmers, J.; Webster, J.; Nowson, C.; Jeffery, P.; Smith, W.; et al. Effects of a community-based salt reduction program in a regional Australian population. BMC Public Health 2016, 16, 388. [CrossRef]

44. Takada, T.; Imamoto, M.; Fukuma, S.; Yamamoto, Y.; Sasaki, S.; Uchida, M.; Miura, Y.; Shimizu, S.; Nihata, K.; Fukuhara, S. Effect of cooking classes for housewives on salt reduction in family members: A cluster randomized controlled trial. Public Health 2016, 140, 144-150. [CrossRef] [PubMed]

45. Park, H.-K.; Lee, Y.; Kang, B.-W.; Kwon, K.-I.; Kim, J.-W.; Kwon, O.-S.; Cobb, L.K.; Campbell, N.R.C.; Blakeman, D.E.; Kim, C.-I. Progress on sodium reduction in South Korea. BMJ Glob. Health 2020, 5, e002028. [CrossRef] [PubMed]

46. Christoforou, A.K.; Dunford, E.K.; Neal, B.C. Changes in the sodium content of Australian ready meals between 2008 and 2011. Asia Pac. J. Clin. Nutr. 2013, 22, 138-143. [CrossRef]

47. Dodd, R.; Ramanathan, S.; Angell, B.; Peiris, D.; Joshi, R.; Searles, A.; Webster, J. Strengthening and measuring research impact in global health: Lessons from applying the FAIT framework. Health Res. Policy Syst. 2019, 17, 48. [CrossRef] [PubMed]

48. Curtis, C.J.; Clapp, J.; Niederman, S.A.; Ng, S.W.; Angell, S.Y. US food industry progress during the National Salt Reduction Initiative: 2009-2014. Am. J. Public Health 2016, 106, 1815-1819. [CrossRef]

49. Mallia, P.; Gauci, C. The use of salt in restaurants. Malta Med. J. 2012, 24, 29-33.

50. Jaworowska, A.; Blackham, T.; Stevenson, L.; Davies, I.G. Determination of salt content in hot takeaway meals in the United Kingdom. Appetite 2012, 59, 517-522. [CrossRef]

51. Korošec, Ž.; Pravst, I. Assessing the average sodium content of prepacked foods with nutrition declarations: The importance of sales data. Nutrients 2014, 6, 3501-3515. [CrossRef]

52. Regan, Á.; Shan, C.L.; Wall, P.; McConnon, Á. Perspectives of the public on reducing population salt intake in Ireland. Public Health Nutr. 2016, 19, 1327-1335. [CrossRef]

53. Pravst, I.; Lavriša, Ž.; Kušar, A.; Miklavec, K.; Žmitek, K. Changes in average sodium content of prepacked foods in Slovenia during 2011-2015. Nutrients 2017, 9, 952. [CrossRef] [PubMed]

54. Antoniolli, R.E.; Atkinson, L.F.; Palmer, M.A. Total lunchtime fast food purchases were lower in sodium and saturated fat when nutritionally promoted fast foods were ordered instead of traditional fast foods: A pilot study. Nutr. Diet. 2014, 71, 41-45. [CrossRef]

55. Bolton, K.A.; Webster, J.; Dunford, E.K.; Jan, S.; Woodward, M.; Bolam, B.; Neal, B.; Trieu, K.; Reimers, J.; Armstrong, S.; et al. Sources of dietary sodium and implications for a statewide salt reduction initiative in Victoria, Australia. Br. J. Nutr. 2020, 123, 1165-1175. [CrossRef] [PubMed]

56. Grimes, C.A.; Kelley, S.-J.; Stanley, S.; Bolam, B.; Webster, J.; Khokhar, D.; Nowson, C.A. Knowledge, attitudes and behaviours related to dietary salt among adults in the state of Victoria, Australia 2015. BMC Public Health 2017, 17, 532. [CrossRef]

57. Trieu, K.; Ieremia, M.; Santos, J.; Neal, B.; Woodward, M.; Moodie, M.; Bell, C.; Snowdon, W.; Faumuina, T.; Webster, J. Effects of a nationwide strategy to reduce salt intake in Samoa. J. Hypertens. 2018, 36, 188-198. [CrossRef]

58. Levi, R.; Probst, Y.; Crino, M.; Dunford, E. Evaluation of Australian soup manufacturer compliance with national sodium reduction targets. Nutr. Diet. J. Dietit. Assoc. Aust. 2018, 75, 200-205. [CrossRef]

59. Kim, M.K.; Lee, K.G. Consumer awareness and interest toward sodium reduction trends in Korea. J. Food Sci. 2014, 79, S1416-S1423. [CrossRef] 
60. Lee, J.; Park, S. Consumer attitudes, barriers, and meal satisfaction associated with sodium-reduced meal intake at worksite cafeterias. Nutr. Res. Pract. 2015, 9, 644-649. [CrossRef] [PubMed]

61. Lee, J.; Park, S. Management of sodium-reduced meals at worksite cafeterias: Perceptions, practices, barriers, and needs among food service personnel. Osong Public Health Res. Perspect. 2016, 7, 119-126. [CrossRef]

62. Ahn, S.-H.; Kwon, J.S.; Kim, K.; Lee, Y.; Kim, H.-K. Current status, perception and practicability of restaurant staffs related to reducing sodium use in Seongnam, Korea. J. Nutr. Health 2019, 52, 475-487. [CrossRef]

63. Ma, G.X.; Shive, S.; Zhang, Y.; Aquilante, J.; Tan, Y.; Zhao, M.; Solomon, S.; Zhu, S.; Toubbeh, J.; Colby, L.; et al. Knowledge, perceptions, and behaviors related to salt use among Philadelphia Chinese take-out restaurant owners and chefs. Health Promot. Pract. 2014, 15, 638-645. [CrossRef] [PubMed]

64. Harnack, L.J.; Cogswell, M.E.; Shikany, J.M.; Gardner, C.D.; Gillespie, C.; Loria, C.M.; Zhou, X.; Yuan, K.; Steffen, L.M. Sources of sodium in US adults from 3 geographic regions. Circulation 2017, 135, 1775-1783. [CrossRef]

65. Dunford, E.K.; Poti, J.M. Simulating the impact of sodium reduction from packaged foods on population sodium intake in US adults and children. Public Health Nutr. 2020, 23, 488-495. [CrossRef]

66. Marakis, G.; Tsigarida, E.; Mila, S.; Panagiotakos, D.B. Knowledge, attitudes and behaviour of Greek adults towards salt consumption: A Hellenic Food Authority project. Public Health Nutr. 2014, 17, 1877-1893. [CrossRef] [PubMed]

67. Vanderlee, L.; Hammond, D. Does nutrition information on menus impact food choice? Comparisons across two hospital cafeterias. Public Health Nutr. 2014, 17, 1393-1402. [CrossRef]

68. Lacey, M.; Chandra, S.; Tzianetas, R.; Arcand, J. Evaluation of actions, barriers, and facilitators to reducing dietary sodium in health care institutions. Food Sci. Nutr. 2018, 6, 2337-2343. [CrossRef] [PubMed]

69. Enkhtungalag, B.; Batjargal, J.; Chimedsuren, O.; Tsogzolmaa, B.; Anderson, C.S.; Webster, J. Developing a national salt reduction strategy for Mongolia. Cardiovasc. Diagn. Ther. 2015, 5, 229-237. [CrossRef]

70. Do, H.T.; Santos, J.A.; Trieu, K.; Petersen, K.; Le, M.B.; Lai, D.T.; Bauman, A.; Webster, J. Effectiveness of a Communication for Behavioral Impact (COMBI) intervention to reduce salt intake in a Vietnamese province based on estimations from spot urine samples. J. Clin. Hypertens. 2016, 18, 1135-1142. [CrossRef]

71. Nilson, E.A.F.; Spaniol, A.M.; Gonçalves, V.S.S.; Oliveira, M.L.; Campbell, N.; L'Abbé, M.; Jaime, P.C. The impact of voluntary targets on the sodium content of processed foods in Brazil, 2011-2013. J. Clin. Hypertens. 2017, 19, 939-945. [CrossRef]

72. Okuda, M.; Asakura, K.; Sasaki, S. Placing salt/soy sauce at dining tables and out-of-home behavior are related to urinary sodium excretion in Japanese secondary school students. Nutrients 2017, 9, 1290. [CrossRef]

73. Sparks, E.; Paterson, K.; Santos, J.A.; Trieu, K.; Hinge, N.; Tarivonda, L.; Snowdon, W.; Johnson, C.; Webster, J. Salt-related knowledge, attitudes, and behaviors on Efate Island, Vanuatu. Int. J. Environ. Res. Public Health 2019, 16, 1027. [CrossRef]

74. Arcand, J.; Blanco-Metzler, A.; Benavides Aguilar, K.; L'Abbe, M.R.; Legetic, B. Sodium levels in packaged foods sold in 14 Latin American and Caribbean countries: A food label analysis. Nutrients 2019, 11, 369. [CrossRef] [PubMed]

75. Temme, E.H.M.; Hendriksen, M.A.H.; Milder, I.E.J.; Toxopeus, I.B.; Westenbrink, S.; Brants, H.A.M.; van der A, D.L. Salt reductions in some foods in The Netherlands: Monitoring of food composition and salt intake. Nutrients 2017, 9, 791. [CrossRef]

76. Hendriksen, M.A.H.; Verkaik-Kloosterman, J.; Noort, M.W.; van Raaij, J.M.A. Nutritional impact of sodium reduction strategies on sodium intake from processed foods. Eur. J. Clin. Nutr. 2015, 69, 805-810. [CrossRef]

77. Yang, Y.X.; Gao, C.; Wang, Z.; Wang, Y.Y.; Lai, J.Q.; Ding, G.G. Introduction to guidelines for salt reduction in Chinese food industry. Zhonghua Yu Fang Yi Xue Za Zhi 2019, 53, 549-552. [CrossRef] [PubMed]

78. Wang, M.; Moran, A.E.; Liu, J.; Coxson, P.G.; Penko, J.; Goldman, L.; Bibbins-Domingo, K.; Zhao, D. Projected impact of salt restriction on prevention of cardiovascular disease in China: A modeling study. PLoS ONE 2016, 11, e0146820. [CrossRef]

79. Van Buren, L.; Dötsch-Klerk, M.; Seewi, G.; Newson, R.S. Dietary impact of adding potassium chloride to foods as a sodium reduction technique. Nutrients 2016, 8, 235. [CrossRef]

80. Hendriksen, M.A.H.; Geleijnse, J.M.; van Raaij, J.M.A.; Cappuccio, F.P.; Cobiac, L.C.; Scarborough, P.; Nusselder, W.J.; Jaccard, A.; Boshuizen, H.C. Identification of differences in health impact modelling of salt reduction. PLoS ONE 2017, 12, e0186760. [CrossRef]

81. Hendriksen, M.A.H.; van Raaij, J.M.A.; Geleijnse, J.M.; Breda, J.; Boshuizen, H.C. Health gain by salt reduction in Europe: A modelling study. PLoS ONE 2015, 10, e0118873. [CrossRef]

82. Coxson, P.G.; Cook, N.R.; Joffres, M.; Hong, Y.; Orenstein, D.; Schmidt, S.M.; Bibbins-Domingo, K. Mortality benefits from US population-wide reduction in sodium consumption: Projections from 3 modeling approaches. Hypertension 2013, 61, 564-570. [CrossRef] [PubMed]

83. Mahat, D.; Isa, Z.M.; Mohd Tamil, A.; Mahmood, M.; Othman, F.; Ambak, R. The association of knowledge, attitude and practice with 24 hours urinary sodium excretion among Malay healthcare staff in Malaysia. Int. J. Public Health 2017, 7, 860-970.

84. Haron, H.; Hiew, I.; Shahar, S.; Michael, V.; Ambak, R. A survey on salt content labeling of the processed food available in Malaysia. Int. J. Environ. Res. Public Health 2020, 17, 2469. [CrossRef]

85. Kaldor, J.C.; Thow, A.M.; Schönfeldt, H. Using regulation to limit salt intake and prevent non-communicable diseases: Lessons from South Africa's experience. Public Health Nutr. 2019, 22, 1316-1325. [CrossRef] [PubMed]

86. Allemandi, L.; Tiscornia, M.V.; Ponce, M.; Castronuovo, L.; Dunford, E.; Schoj, V. Sodium content in processed foods in Argentina: Compliance with the national law. Cardiovasc. Diagn. Ther. 2015, 5, 197-206. [CrossRef] [PubMed] 
87. European Commission. Survey on Members States' Implementation of the Salt Reduction Framework; European Commission: Brussels, Belgium, 2014.

88. Peters, S.A.E.; Dunford, E.; Ware, L.J.; Harris, T.; Walker, A.; Wicks, M.; van Zyl, T.; Swanepoel, B.; Charlton, K.E.; Woodward, M.; et al. The sodium content of processed foods in South Africa during the introduction of mandatory sodium limits. Nutrients 2017, 9, 404. [CrossRef]

89. Sarmugam, R.; Worsley, A.; Wang, W. An examination of the mediating role of salt knowledge and beliefs on the relationship between socio-demographic factors and discretionary salt use: A cross-sectional study. Int. J. Behav. Nutr. Phys. Act. 2013, 10, 25. [CrossRef] [PubMed]

90. Haron, H.; Kamal, N.F.; Yahya, H.M.; Shahar, S. Knowledge, attitude and practice (KAP) of Malay elderly on salt intake and its relationship with blood pressure. Front. Public Health 2020, 8, 559071. [CrossRef] [PubMed] 